Kajian Jurnalisme

ISSN 2549-0559 (cetak) ISSN 2549-1946 (online)

Volume 01 Nomor 02 Tahun 2018

\title{
Manajemen Strategi Redaksi Dan Bisnis Koran Olahraga Topskor Dalam Menghadapi Persaingan Dengan Media Online Di Era Konvergensi Media
}

\author{
Nur Cholis dan Dian Wardiana \\ Program Studi Ilmu Jurnalistik, Fakultas Ilmu Komunikasi, Univeristas Padjadjaran \\ E-mail: ncholis47@gmail.com
}

\begin{abstract}
The aim of this research was to find out how Topskor classified its rivalry and how the application of editorial and business management strategy in Topskor. This research was reviewed based on Topskor's reasons to stay using newspaper platform and based on the pattern of canvas business model. To elaborate, this research used the qualitative research method with explanatory case study of Robert K. Yin models approachment. The results showed that Topskor's editorial has three methods facing its online media rivalry, such as making a long form of article and providing data by picture or infographic. Those ways were organized by editorial management so that the quality content can be maintained. In Business, Topskor has four sources of income which are newspaper, advertisement, and event. However, those strategies were rarely practiced by online media. The conclusion of this research were edtitorial dan business strategy of Topskor had been applied by online media. The speed of information in online media was difficult to be defeated by print media because of its periodical character. In terms of business, online media also did the same thing by creating advertising and event cooperation. Researcher suggests that Topskor can do media convergence so that it will create content innovation either in its newspaper or online. Beside that, marketing team of Topskor can open another business opportunity so that the company will not just stand in newspaper, advertisement, and event as sources of income. For example, Topskor can make the online form of Topskor and social media as another source of income.
\end{abstract}

Keyword: Management, Strategy, Editoral, Business, Topskor, Online Media, Media Convergence.

\begin{abstract}
Abstrak
Penelitian ini bertujuan mengetahui bagaimana Harian Topskor memetakan pesaing mereka dan bagaimana penerapan manajemen strategi redaksi dan bisnis Harian Topskor. Diulas berdasarkan alasan Redaksi Harian Topskor tetap bertahan dalam platform koran dan berdasarkan pola bisnis Topskor berdasarkan model bisnis kanvas. Untuk menguraikannya, penelitian ini menggunakan metode penelitian kualitatif dengan pendekatan studi kasus eksplanatoris model Robert K. Yin.

Hasil penelitian menunjukan, secara redaksional Harian Topskor punya cara dalam menghadapi persaingan dengan media online, yaitu membuat tulisan indepth berupa berita atau analisis pertandingan disertai data dan infografis. Semuanya dilakukan atau diatur lewat manajemen redaksi agar kualitas konten dapat dipertahankan. Secara bisnis, Topskor punya empat pemasukan di antaranya lewat penjualan koran, iklan, rubrikasi, dan aktivasi.
\end{abstract}

http://jurnal.unpad.ac.id/kajian-jurnalisme 
125 | Kajian Jurnalisme

ISSN 2549-0559 (cetak) ISSN 2549-1946 (online)

Volume 01 Nomor 02 Tahun 2018

Namun, secara tidak langsung, strategi-strategi tersebut sudah banyak dipraktikan juga oleh media online. Simpulan dari penelitian ini adalah strategi redaksi dan bisnis Harian Topskor turut diterapkan juga oleh media online. Kecepatan informasi di media online sulit ditandingi oleh media cetak karena sifatnya yang periodik. Dalam hal bisnis, media online juga melakukan hal yang sama dengan membuat kerja sama iklan dan event. Peneliti menyarankan koran Topskor segera konvergensi media, Harian Topskor dapat menciptakan inovasi konten di koran dan Topskor.id. Selain itu, tim marketing Topskor dapat membuka pintu bisnis lain agar perusahaan tidak bertumpu dari pengiklan yang membuat rubrikasi dan event sebagai pemasukan, contohnya membuat Topskor.id dan sosial media Topskor sebagai pintu pemasukan lainnya.

Kata Kunci: Manajemen, Strategi, Redaksi, Bisnis, Topskor, Media online, Konvergensi Medi

\section{Pendahuluan}

Olahraga adalah salah satu kegiatan yang cukup digemari oleh banyak orang, khususnya sepakbola. Menurut data Nielsen pada Juni 2014 tentang negara dengan ketertarikan terhadap sepakbola di dunia, Indonesia berada di peringkat 2 (77\%), kalah dengan Nigeria (83\%) yang berada di posisi paling atas. Unggul jauh dengan Brazil di peringkat 10 dengan persentase 67 persen. Padahal Brazil dikenal sebagai negara yang melahirkan bakat-bakat pemain sepakbola berbakat kelas dunia. Dalam laporan yang sama, ada beberapa cara penggemar sepakbola untuk mencari berita mengenai tim kesukaannya, yaitu lewat televisi (90\%), internet (49\%), koran $(45 \%)$.

Informasi dunia olahraga pun juga tidak bisa dianggap remeh lagi. Senada dengan pernyataan itu, dalam buku Jurnalistik: Teori dan Praktik, dikatakan bahwa hampir setiap surat kabar sekarang punya halaman olahraga sendiri. Informasi olahraga selalu mengisi berbagai format media cetak, entah berbentuk berita artikel, atau tajuk rencana. Televisi dan radio pun menyediakan porsi khusus untuk berita-berita dan peristiwa olahraga dalam siaran beritanya (Kusumaningrat dan Kusumaningrat, 2005: 207).

Sejalan dengan bertambahnya olahraga di dunia, banyak media di Indonesia entah media cetak, elektronik, atau pun online punya rubrik khusus yang membahas olahraga. Setiap akhir pekan banyak pertandingan olahraga yang bisa ditonton. Televisi dan radio pun turut menyiarkan langsung pertandingan olahraga. Media cetak memberikan laporan pertandingan atau analisis sebelum dan sesudah pertandingan beserta statistiknya. Dalam media cetak, Harian Kompas memuat berita olahraga sebanyak tiga halaman atau Jawa Pos yang menempatkan olahraga dalam rubrik Sportaiment. Dalam ajang olahraga tertentu, seperti Piala Dunia, halaman dan porsi berita olahraga bisa ditambah lebih banyak, bahkan bisa menjadi headline atau laporan utama (Prarstya, 2014: 46). Selain hadir dalam bentuk rubrik atau halaman tertentu, saat ini hadir juga media yang khusus membahas dunia olahraga dengan berbagai format, misalnya Harian Topskor yang hadir dalam format cetak, Metro Sport dalam program televisi, dan Detiksport dalam bentuk situs berita online.

Khusus yang peneliti sebutkan pertama, Harian Topskor hadir sebagai pelopor terbitnya harian atau koran olahraga di Indonesia. Banyak anggapan bahwa media olahraga yang pertama ada di Indonesia adalah Tabloid Bola. Ternyata anggapan tersebut salah. Tabloid Bola baru 
Kajian Jurnalisme

ISSN 2549-0559 (cetak) ISSN 2549-1946 (online)

Volume 01 Nomor 02 Tahun 2018

hadir dengan format koran atau harian pada tahun 2013. Sedangkan koran olahraga pertama adalah Topskor pada 6 Januari 2005 (Prarstya, 2014: 48).

Harian Topskor hadir sebagai pendobrak kehadiran koran olahraga yang memberikan berita dan informasi seputar dunia olahraga. Dengan tagline Harian Olahraga Nomor satu di Indonesia, Topskor menyajikan berita yang langsung, lugas, dan eksklusif.

Berdasarkan wawancara pra-riset peneliti dengan Wakil Pemimpin Redaksi Topskor, Irfan Sudrajat, tagline tersebut digunakan sebagai andalan Topskor dalam merebut hati pembaca. Hal tersebut dibuktikan atas kerja sama Harian Topskor dengan media olahraga asing La Gazetta Dello Sport (Italia) dan Marca (Spanyol). Sebenarnya, bentuk kerja sama ini bukan yang pertama ada di Indonesia. Sebelumnya ada Harian Bola yang bekerja sama dengan Fourfourtwo, media asing asal Inggris.

Kerja sama Harian Topskor dengan dua media tersebut sebatas kerja sama informasi, artinya pihak La Gazetta Dello Sport dan Marca akan memberikan berita dalam format tulisan dari wartawannya ke Harian Topskor. Tulisan tersebut bisa ditempatkan di headline atau halaman lainnya. Contohnya berita seputar Piala Dunia Rusia 2018 yang ada di Harian Topskor ditulis oleh salah satu wartawan dari dua media tersebut beserta kejadian yang ada di lapangan. Selain laporan pertandingan, wartawan juga bisa memberikan analisis sebelum atau setelah pertandingan.

Meskipun menganggap dirinya menjadi koran olahraga nomor 1 di Indonesia, Harian Topskor ternyata punya kendala berupa oplah koran yang turun dalam beberapa tahun terakhir. Menurut Manajer Sirkulasi dan Distribusi Harian Topskor, Fardan Mustika, oplah Harian Topskor terus mengalami penurunan setiap tahunnya.

Tabel 1. Oplah Harian Topskor dalam dua tahun terakhir

\begin{tabular}{|r|c|l|}
\hline Tahun & Total Kirim ke Agen & Oplah \\
\hline 2016 & 154.000 & 138.600 \\
\hline 2017 & 154.000 & 123.200 \\
\hline
\end{tabular}

(Sumber: PT. Topskor Indonesia, 2018)

Namun, menurunnya oplah enggan membuat Topskor mengurangi jumlah koran yang dikirim ke agen. Karena banyak kegiatan olahraga tiap tahunnya yang bisa dibuat berita. Hal senada disampaikan juga oleh Manajer Marketing Topskor, Haderis Alkaf. Menurutnya salah satu pendapatan terbesar Topskor adalah dari koran. Selain iklan, pendapatan juga masih didominasi oleh penjualan koran.

Turunnya oplah tidak dirasakan oleh Topskor saja. Berdasarkan data Serikat Perusahaan Pers, sejak 2008-2014, oplah harian menunjukan tren naik, meski medianya naik turun. Namun, kenaikan itu berhenti pada 2014. Pada 2015, oplah mulai menurun di angka 8,79 juta atau turun sebesar 8,9 persen dari tahun sebelumnya. Pada tahun 2015 oplah majalah, tabloid, dan mingguan juga ikut merosot sekitar 9,27 persen dibanding tahun 2014. 
127 | Kajian Jurnalisme

ISSN 2549-0559 (cetak) ISSN 2549-1946 (online)

Volume 01 Nomor 02 Tahun 2018

Menurut laporan Tirto.id pada 8 Februari 2017 yang ditulis oleh Wan Ulfa Nur Zuhra, dari tahun 2014-2016 terjadi peningkatan media cetak yang mati, entah koran, harian serta majalah mingguan. Total ada 16 media cetak yang tutup. Bahkan Harian Bola terbit kurang dari 4 tahun ikut gulung tikar. Media cetak besar seperti Koran Tempo Minggu, Sinar Harapan, Tabloid Gaul, Soccer, dan Majalah Sastra Horison ikut jejak yang sama. salah satu penyebabnya adalah penurunan oplah.

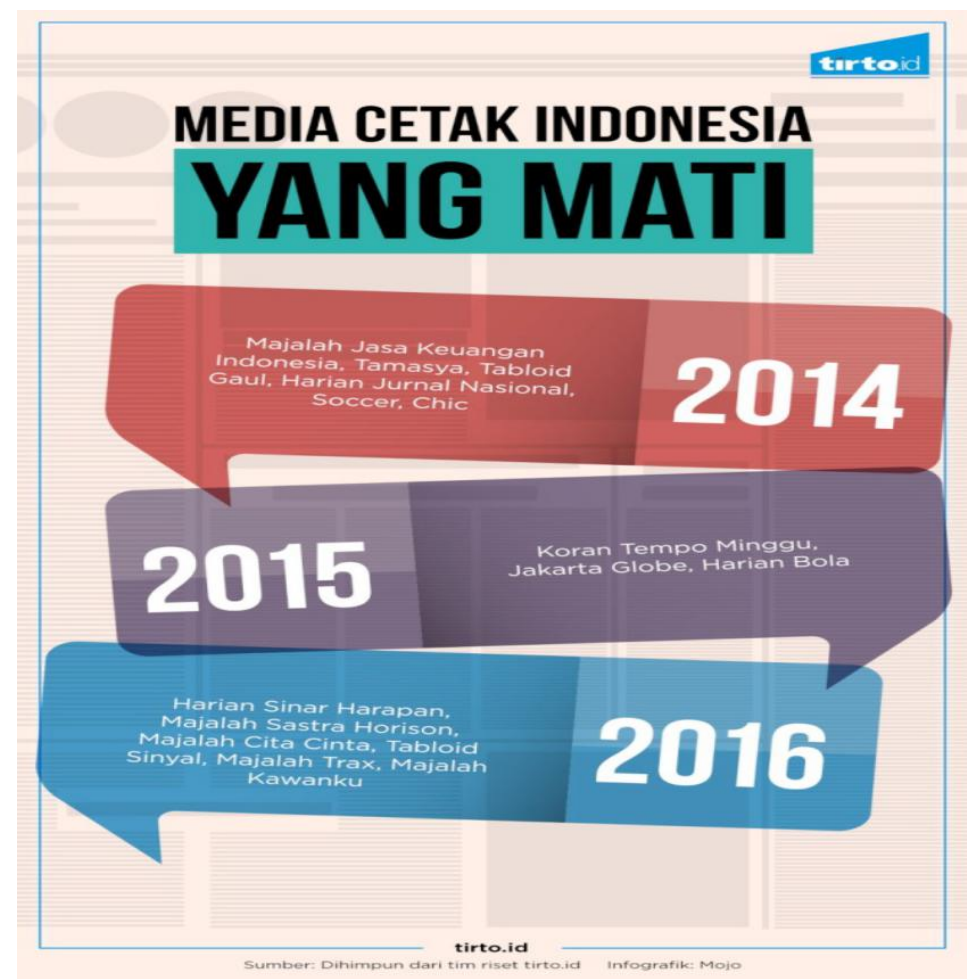

Gambar 1. infografis Tirto.id tentang media cetak yang gulung tikar

Sedangkan menurut laporan Tirto.id pada tanggal 8 Februari 2017 yang ditulis oleh Wan Ulfa Nur Zuhra, banyak media cetak yang turun oplahnya disebabkan kurangnya manajemen media dalam merespon khalayak dalam memperoleh informasi dan justru mengabaikan internet sebagai salah satu penggilas koran. Lebih dari itu, banyak media justru harus tutup dan tidak terbit lagi dalam bentuk cetak. Bukan media nasional saja yang tutup, tetapi media olahraga terkena imbasnya.

Dari data tersebut, apa yang ditulis oleh Wan Zulfa mungkin ada benarnya. Salah satu penyebabnya adalah karena manajemen yang tidak responsif saat semakin masifnya penggunaan internet. Berdasarkan dari data itu juga, peneliti beranggapan kematian media cetak mungkin bisa terjadi oleh Harian Topskor bila tidak merespon perkembangan teknologi. Di sisi lain, meskipun khalayak banyak yang mencari informasi olahraga, tetap saja membuat media cetak olahraga tutup. Harian Bola dan Tabloid Soccer adalah contoh media cetak olahraga yang tutup karena alasan bisnis dan oplah yang semakin menurun. 
Banyak anggapan bahwa penyebab tersendatnya oplah media cetak adalah kehadiran media online. Pernyataan tersebut bisa terjadi dengan adanya internet, tempat bernaung media online. Media online memberikan kecepatan informasi dibandingkan dengan media cetak, termasuk berita olahraga. Banyak komentar lain bahwa berita olahraga tergolong cepat berubah, karena laporan pertandingan dapat diunggah secepat mungkin di situs-situs media online. Dalam buku Jurnalistik Online, James C. Foust mengemukakan keunggulan jurnalistik online, beberapa karakteristiknya adalah immediacy (kesegaran), artinya berita bersifat cepat dan langsung dan Storage and retrieval, berita dapat disimpan dan diakses lagi kapan pun (Romli, 2012: 6). Dalam konteks berita olahraga, khalayak tidak perlu menonton tv atau membeli koran untuk mengetahui hasil pertandingan. Di media online, semua laporan pertandingan dari berbagai negara di dunia bisa diketahui beserta video cuplikannya.

Pada tahun 2017, menurut data Asosiasi Penyelenggara Jasa Internet Indonesia, berdasarkan penetrasi pengguna internet berdasarkan usia, dari umur 13-18 tahun berada di angka 75,50\% . Sedangkan umur 19-34 berada di angka 74,23\%. Angka ini cukup besar dan didominasi oleh generasi milenial yang sudah terbiasa menggunakan internet. Sedangkan menurut komposisi pengguna internet berdasarkan usia, angka tertinggi ada di angka 49,52 persen dengan usia 19-34 tahun. Kedua ditempati usia 35-54 tahun dengan angka 29,55 persen.

Merujuk data yang sama, berdasarkan pemanfaatan internet di bidang edukasi, gaya hidup, sosial politik dan informasi kesehatan, pencarian informasi masih tergolong tinggi yaitu baca artikel $(55,30 \%)$, media sosial $(87,13 \%)$, dan berita sosial dan lingkungan $(50,26 \%)$, serta cari informasi kesehatan $(51,06 \%)$. Data ini menunjukan bahwa pencarian informasi atau berita tidak hanya di media berbentuk cetak, tetapi dalam bentuk digital.

Dengan data tersebut, peneliti beranggapan bahwa banyak orang saat ini sering menggunakan internet dalam berbagai hal, salah satunya mencari informasi atau berita. Dari data ini juga peneliti melihat adanya cara baru dalam masyarakat dalam mencari informasi. Ketika koran punya zaman kejayaannya sendiri dan diandalkan banyak orang sebagai penyedia informasi beberapa dekade lalu, sekarang internet hadir memberi tawaran lebih praktis guna meraih informasi.

Bukan itu saja, ditambah kehadiran telepon genggam atau smartphone semakin memanjakan para penggunanya agar mencari informasi yang diinginkan. Hanya dengan koneksi internet, para pengguna dapat menelusuri berita dengan mudah. Budaya membaca yang konvensional dengan buku dan kertas, sekarang bisa dikalahkan oleh sebuah teknologi smartphone.

Dengan keberadaan internet, hadir pula istilah new media atau media baru. Menurut Chun, new media merupakan pernyederhanaan istilah terhadap bentuk media di luar lima media massa konvensional, yaitu televisi, radio, majalah, koran, dan film. Sifat new media adalah cair (fluids), konektivitas individual dan menjadi sarana untuk membagi peran kontrol dan kebebasan (Romli, 2012:31).

New Media merujuk pada perkembangan teknologi digital, tetapi news media bukan berarti berbentuk digital. Teks, gambar, video, ataupun grafik diubah menjadi data-data (byte), hanya 
129 | Kajian Jurnalisme

ISSN 2549-0559 (cetak) ISSN 2549-1946 (online)

Volume 01 Nomor 02 Tahun 2018

merujuk pada sisi teknologi multimedia. Artinya, semua konten bisa ada di banyak platform, entah itu cetak atau digital.

Menurut McQuail (2011: 42), sejak tahun 1960-an, istilah new media sudah cukup terkenal. New media sudah mencakup seperangkat teknologi komunikasi terapan yang semakin berkembang dan beragam. Penyebab kemunculan media baru adalah teknologi digital yang semakin berkembang. Karakteristik media baru yang paling utama menurut McQuail adalah saling berhubungnya akses terhadap khalayak individu sebagai penerima maupun pengirim pesan, interaksinya, kegunaannya yang beragam sebagai karakter yang terbuka, dan sifatnya yang ada di mana-mana.

Bila merujuk istilah yang peneliti paparkan di paragraf sebelumnya, hal ini dapat dikaitkan dengan keberadaan media online. Dalam buku Jurnalistik Online, dijelaskan bahwa media online adalah produk jurnalistik online atau cyber journalism yang didefinisikan sebagai pelaporan fakta atau peristiwa yang yang diproduksi dan distribusikan melalui internet (Romli, 30: 2012).

Menurut Ward dalam buku Journalism Online (2002:9), kegiatan online adalah ketika khalayak sedang mengakses internet via modem atau telepon. Pun dengan koran yang memiliki versi online atau situsnya sendiri, bisa juga disebut sebagai koran online. Ward (2002:21-25) menjelaskan beberapa karakteristik yang ada pada jurnalisme online, yaitu pertama, immediacy atau kesegeraan. Karakteristik pertama yang terdapat pada jurnalisme online adalah kesegaran atau kecepatan dalam menyampaikan informasinya.

Kedua, Multiple Pagination atau pemberitaan halaman secara sekaligus. Sebuah website bisa memiliki ratusan halaman yang terpisah-pisah, tetapi halaman tersebut bisa memiliki koneksi dan bisa dibaca oleh khalayak karena adanya ketertarikan berita.

Ketiga, Multimedia atau menyajikan gabungan teks, gambar, audio, video, dan grafis secara sekaligus. Multimedia menyediakan berbagai jenis bentuk jurnalistik.

Keempat, Archieving atau mengarsipkan. Dengan adanya jurnalime online, berita dapat dikelompokan berdasarkan kategori (rubric) atau kata kunci (keywords) dan teks bisa tersimpan dan diakses kapan pun.

Kelima, Relationship with reader, interactivity atau interaksi dengan khalayak. Kontak atau interaksi dengan pembaca dapat terjadi secara langsung melalui kolom komentar lainnya.

Dengan karakteristik tersebut, ada kecenderungan orang lebih sering membuka media online dari pada membaca koran karena sifatnya yang perioditas dan kalah aktualitas dengan media online. Selain membaca teks, pembaca media online bisa mengakses audio dan video dalam waktu bersamaan. Tentu itu semua tidak bisa dilakukan oleh media cetak.

Pembaca koran yang biasanya harus beli beberapa koran untuk tahu sebuah peristiwa kini bisa membuka media online untuk baca berita. Khalayak tidak perlu berlangganan atau ke tukang koran untuk membeli koran. Dengan adanya media online, banyak berita dan informasi yang bisa dicari dalam waktu yang bersamaan. Singkatnya media online memberikan kemudahan mencari informasi bagi penggunanya. Dari beberapa data dan pernyataan tersebut, kehadiran media online di internet cukup memberikan dampak bagi turunnya oplah koran. 
Dalam konteks media olahraga, menurut Alexa.com, situs media online olahraga yang sering diakses (dalam skala nasional) adalah bola.com (peringkat 27), bolasport.com (peringkat 34), dan bola.net (peringkat 40). Dalam survei berjudul 'The Browser Satiffactory Index' yang dilakukan Opera di situs www.digitalnewsasia.com, mengatakan salah satu kecenderungan lelaki dalam menggunakan internet adalah mengakses informasi atau berita olahraga. Seperti yang digambarkan dalam company profile, Topskor mengincar pembaca dari usia 20-29 tahun dan didominasi oleh pria, di sisi lain penetrasi internet juga didominasi dari umur yang sama. Ini menandakan Topskor harus bisa bersaing dengan khalayak yang lebih sering berselancar di dunia maya. Topskor harus memiliki keunggulan agar bisa dilirik terus oleh pembaca.

Dengan oplah yang semakin berkurang dan kehadiran media online, Topskor memiliki beberapa cara agar tetap bertahan. Beberapa di antaranya adalah mengadakan kompetisi sepakbola bertajuk Kompetisi Usia Muda Liga Topskor dan Nonton Bareng MotoGP.

Menurut Haderis Alkaf, kegiatan tersebut dilakukan demi menutupi dana operasional oplah koran. Dari kegiatan itu, Topskor bisa menggaet pengiklan dan membuat artikel advertorial. "Dua kegiatan itu salah satu cara supaya ongkos untuk menambal uang oplah," ujar Haderis Alkaf.

Dari sisi redaksi salah satu cara yang dilakukan Topskor untuk bertahan menghadapi persaingan dengan media online adalah konvergensi media, yaitu membuat situs Topskor.id. Menurut Manajer Marketing Topskor, Haderis Alkaf, meskipun pendapatan dari situs belum maksimal, tapi setidaknya bisa menambal pengeluaran lainnya. Menurut Wakil Pemimpin Redaksi Harian Topskor, Irfan Sudrajat praktik sistem cetak dan online (multiplatform) yang ada harus bisa disesuaikan dengan manajemen yang baik, khususnya di era digital. Harian Topskor adalah salah satu media yang masih beradaptasi dengan teknologi digital.

Dalam penelitian berjudul "Sejarah Konvergensi Media dalam Konteks Keindonesiaan", konvergensi adalah menggabungkan semua platform media dalam bentuk digital, kemudian bisa dikonsumsi lewat satu perangkat, entah itu gawai, komputer, atau laptop. Media massa di Indonesia yang sudah melakukan konvergensi adalah Kompas dengan membentuk Kompas Gramedia Group (KGG) dan mengusung semboyan 3M (Multimedia, Multiplatform, dan Multichannel).

Dalam penelitian tersebut, disebutkan juga konvergensi yang dilakukan secara vertikal dan horizontal. Secara vertikal, KGG melakukan konvergensi industri dengan membuka toko buku Gramedia tahun 1970 dan percetakan Gramedia tahun 1972. Secara horizontal KGG mendirikan unit bisnis radio Sonora FM dan Otomotion FM. Mereka juga melakukan digitalisasi media dengan membuat situs www.kompas.com dan menyediakan konten online, e-paper, dan kompasiana (Prasetyadi, 10-11: 2014).

Dari permasalahan yang peneliti paparkan sebelumnya, peneliti ingin mengetahui bagaimana manajemen redaksi dan bisnis dalam menghadapi persaingan dengan media online di era konvergensi media. Dari berbagai macam media olahraga yang ada di Indonesia, ada beberapa alasan peneliti memilih Topskor sebagai objek yang akan diteliti. Pertama, Topskor adalah koran olahraga pertama di Indonesia. Kedua, perbincangan senjakala media cetak sedang ramai diperbincangkan saat ini, termasuk dalam media cetak olahraga. Sebagai contoh, ada 
131 | Kajian Jurnalisme

ISSN 2549-0559 (cetak) ISSN 2549-1946 (online)

Volume 01 Nomor 02 Tahun 2018

beberapa media cetak olahraga yang sudah tutup seperti Harian Bola, FourFourTwo Indonesia, dan Tabloid Soccer. Ditambah persaingan dengan media online olahraga juga semakin ketat karena bertarung dalam menyampaikan informasi ter-update.

Dalam kecepatan, media cetak mungkin punya kelemahan. Tapi dalam urusan kepercayaan, media cetak masih dapat diandalkan. Berdasarkan survei yang dilaporkan pada tanggal 6 Desember 2017 oleh Nielsen Consumer \& Media View (CMV), pada kuartal III 2017 yang dilakukan di 11 kota dan mewawancara 17 ribu responden. Hasilnya adalah saat ini media cetak (termasuk koran, majalah dan jabloid) memiliki penetrasi sebesar 8 persen dan dibaca oleh 4,5 juta orang. Dari jumlah tersebut, 83 persen membaca koran. Alasan utama para pembaca masih memilih koran adalah karena nilai beritanya yang dapat dipercaya. Menurut peneliti, pernyataan tersebut bisa menjadi peluang bagi Topskor untuk bertahan dan meraih hati pembaca. Tentu juga untuk meraih oplah dan pendapatan sebanyak-banyaknya.

Ketiga, belum ada media massa olahraga juga yang gencar mengadakan pola bisnis seperti yang dilakukan Topskor dengan membuat kompetisi liga usia muda untuk mempertahankan eksistensinya. Berdasarkan pra-riset yang dilakukan peneliti terhadap dua media online olahraga, bola.com dan bolasport.com, mereka membuat cara yang sama, tapi tidak konsisten setiap tahun.

Dalam penelitian ini, peneliti ingin mengetahui bagaimana manajemen redaksi Harian Topskor menghadapi persaingan dengan media online di era konvergensi media. Selain itu, berbicara tentang media, kemungkinan besar ada aspek bisnis di dalamnya. Itu dibuktikan dengan pengaruhnya oplah Topskor yang turun, membuat mereka harus mengadakan kegiatan lain demi menutup ongkos kertas dan percetakan.

Untuk membedah itu semua tentu diperlukan sebuah metodologi penelitian sehingga penelitian yang dilakukan peneliti terarah. Peneliti akan menggunakan metode studi kasus. Studi kasus adalah salah satu metode penelitian ilmu-ilmu sosial, secara umum studi kasus merupakan strategi yang lebih cocok bila pokok pertanyaan suatu penelitian berkenaan dengan "how" dan "why", bila penelitian hanya sedikit dan bilamana fokus penelitiannya terletak pada fenomena kontemporer di dalam konteks kehidupannya (Yin, 2014: 1).

Yin membagi metodologinya ke dalam tiga hal berdasarkan tujuan dan tipe pertanyaan, di antaranya ada eksploratoris, deskriptif, dan eksplanatoris. Eksploratoris lebih menitikberatkan pada pertanyaan apa, deskriptif, pada pertanyaan "apakah, siapakah, dan di manakah", sedangkan ekslanatoris pada pertanyaan "bagaimana dan mengapa". Pada penelitian ini, peneliti menggunakan jenis studi kasus eksplanatoris. Alasannya karena dasar pertanyaannya adalah bagaimana manajemen strategi redaksi dan bisnis Harian Topskor dalam menghadapi persaingan dengan media online.

Selain itu, untuk menganalisis manajemen redaksi Topskor, peneliti menggunakan konsep manajemen redaksi Conrad C. Fink. Fink (1998:136) yang berpendapat bahwa ada empat tahapan utama dalam manajemen redaksi untuk memproduksi materi pemberitaan berkualitas, yaitu perencanaan, pengorganisasian, penggerakan, dan pengawasan dalam konteks manajemen redaksional. Konsep tersebut biasa dikenal dengan planning, organizing, actuating, dan controlling (POAC). 
Sedangkan untuk melihat aspek bisnis yang ada di Harian Topskor, peneliti menggunakan model kanvas. Menurut buku Business Model Generation, digunakan untuk menggambarkan dasar pemikiran tentang bagaimana organisasi membuat, memberikan dan menangkap hal-hal, seperti ekonomi, sosial, dan lain sebagainya (Osterwalder \& Pigneur, 2010). Artinya, dalam menanggapi perubahan baik di dalam maupun di luar, sebuah media dapat menentukan langkah dengan konsep model bisnis. Peneliti juga akan menggunakan konsep SWOT (strength, opportunities, weaknesses, threaths). Analisis SWOT menurut Philip Kotler (2009:63), diartikan sebagai evaluasi terhadap keseluruhan kekuatan, kelemahan, peluang, dan ancaman. Sedangkan menurut Freddy Rangkuti (2013:19), analisis SWOT diartikan sebagai analisa yang didasarkan pada logika yang dapat memaksimalkan kekuatan (strengths) dan peluang (opportunities), namun secara bersamaan dapat meminimalkan kelemahan (weaknesses) dan ancaman (threats).

\section{Hasil Dan Pembahasan}

Persaingan antara media cetak dan media online jadi isu yang sering dibahas oleh para pakar dan praktisi media. Harian Topskor sebagai salah satu media cetak olahraga di Indonesia kalah kecepatan dengan media online. Bukan itu saja, Harian Topskor harus bersaing di tengah pesatnya perkembangan internet.

Berdasarkan wawancara peneliti dengan Wakil Pemimpin Redaksi Harian Topskor, Irfan Sudrajat menganggap persaingan tersebut sebagai suatu hal yang harus dihadapi, karena saat ini informasi bisa dapatkan secara mudah di era digital. Informasi bisa diraih secara gampang. Pembaca tidak perlu membeli koran dan cukup mengakses media tertentu di gawai atau smartphone. Meskipun kalah cepat, Irfan punya pandangan sendiri agar punya ciri khas berbeda dengan media online.

"Kita harus kuat dengan tulisan yang beda. Itu memang tantangan yang susah secara pemikiran. Tapi karena kita sering kita jalanin, jadi tidak berasa. Karena memang sudah begitu. Karena tulisan di Topskor sudah menyongsong di era digital," kata Irfan Sudrajat.

Meskipun begitu, ada permasalahan yang dihadapi, salah satunya media bernaung di grupgrup tertentu. Sedangkan Harian Topskor masih bisa bertahan tanpa grup perusahaan tertentu. Peneliti melihat ada beberapa media, khususnya olahraga yang tergabung dalam grup perusahaan media, seperti Super Ball (dalam naungan Tribun Network) atau bola.com dan bola.net (dalam naungan KapanLagi Youniverse). Mereka disokong dana besar dan media yang ada hampir di setiap daerah di Indonesia.

Irfan Sudrajat mengatakan, persaingan tersebut harus dijaga demi terciptanya persaingan bisnis yang sehat. Jangan saling menjatuhkan sama lain antar media. Semua media harus menyajikan konten menarik untuk pembaca.

Berdasarkan wawancara peneliti dengan Irfan Sudrajat, Topskor turut membandingan kekurangan dan kelebihan mereka agar dapat terus bersaing dengan media online. Perbandingan ini berfungsi untuk meninjau kelebihan dan kekurangan Topskor dari beberapa sisi. Berdasarkan hasil penelitian yang dilakukan peneliti, inilah kelebihan koran Topskor:

- Ketenaran Nama 
133 | Kajian Jurnalisme

ISSN 2549-0559 (cetak) ISSN 2549-1946 (online)

Volume 01 Nomor 02 Tahun 2018

Harian Topskor adalah salah satu media cetak olahraga yang punya nama cukup terkenal di kalangan penyuka olahraga, khususnya sepakbola nasional. Hal ini dikarenakan pendiri Harian Topskor yang terkenal seperti Rony Pangemanan dan Yusuf Kurniawan. Mereka berdua adalah orang yang sering tampil di televisi nasional menjadi komentator di pertandingan olahraga nasional atau pun internasional. Bukan itu saja, Topskor juga memiliki liga usia muda yang aktif melahirkan pesepakbola yang berkualitas dan juara di kompetisi internasional.

- Mendalam

Media cetak memiliki kelebihan yaitu mampu membuat berita atau tulisan panjang. Media online sebenarnya bisa melakukan hal serupa. Tapi mereka dibatasi waktu yang cepat (deadline) untuk menerbitkan berita tersebut. Sifatnya yang selintas membuat media online jarang menyajikan berita mendalam. Hal ini yang selalu menjadi kekuatan Harian Topskor. Tulisan mendalam harus dimanfaatkan karena halaman koran yang wajib diiisi. Bila halaman tersebut diisi dengan tulisan pendek akan menjadi mubazir karena banyak informasi bernilai tinggi yang bisa ditulis.

- Akurat

Harian Topskor memiliki unsur akurat yang lebih baik dibandingkan dengan media online. Akurat bisa dinilai dari analisis dan fakta yang bisa dipertanggungjawabkan kebenarannya. Berbeda dengan media pada umumnya, media olahraga punya konten berisi informasi laporan dan ulasan pertandingan olahraga. Analisis atau ulasan berfungsi agar pembaca punya gambaran atau prediksi sebelum melihat pertandingan. Tetapi, tidak semua prediksi benar karena hasil akhir pertandingan ditentukan di lapangan.

Media cetak juga memiliki lebih banyak waktu untuk melakukan proses penulisan berita mulai dari meliput, mengedit, menyaring, hingga waktu terbit koran, sehingga jumlah kesalahan dapat diminimalisir.

- Data

Menurut Irfan, salah satu kekuatan Harian Topskor adalah data. Hal ini dibuktikan lewat infografis dan gambar di halaman harian Topskor. Infografis dan gambar biasanya berisi data yang berisikan head to head antar klub, statistik pemain, dan laporan pertandingan. Data adalah elemen penting karena khalayak suka tulisan analisis beserta data. Meskipun media online olahraga banyak melakukan cara serupa, tetapi kecepatan berita di media online sulit ditandingi. Media online biasanya hanya melaporkan pertandingan, jarang disertai data dan analisis mendalam. Terlebih Topskor bekerja sama dengan media asing, La Gazetta Dello Sport dan Marca, sehingga data yang disajikan lebih akurat.

Namun Harian Topskor tetap tidak memungkiri masih terdapat kekurangan dibanding media online. Kekurangan tersebut adalah:

- Kecepatan berita

Kecepatan adalah salah satu kekurang Harian Topskor yang sulit dihindar. Harian Topskor butuh distribusi panjang untuk menerbitkan berita guna sampai ke khalayak. Apalagi untuk mengolah data menjadi sebuah tulisan analisis membutuhkan waktu yang lama. Wartawan harus meliput dan mengumpulkan informasi lengkap serta verifikasi kepada informan. Informasi kemudian diolah, diedit, dan disaring agar menjadi tulisan atau berita. Sedangkan 
media online tidak mengalami proses yang panjang. Media online perpacu dengan waktu untuk menerbitkan berita secepat mungkin sehingga proses penyaringan informasi menjadi kurang ketat, bahkan kadang diabaikan. Kadang tak jarang berita yang salah atau kurang akurat dihapus demi kebaikan nama media tersebut.

- Kemudahan akses berita

Media online lebih mudah diakses dengan perangkat keras seperti komputer, laptop, atau gawai yang terhubung koneksi internet. Khalayak dapat mengakses berita olahraga atau streaming pertandingan olahraga. Khalayak juga tidak perlu mengeluarkan tenaga lebih ke loper atau penjual koran untuk membeli dan membaca sebuah koran dan tentunya hal tersebut juga mengeluarkan uang

- Multimedia

Media online dengan segala keberagamannya mampu menyajikan berbagai konten, contohnya video, tulisan, dan gambar dalam satu halaman atau satu berita. Hal ini tentu berbeda dengan media cetak yang tidak bisa menyertakan video di dalamnya. Kelebihan ini menjadi salah satu nilai jual media cetak bagi khalayak.

Dari segi kecepatan dan kemudahan, Harian Topskor kalah bersaing dengan media online. Namun, bukan berarti Harian Topskor menyerah dengan keadaan. Agar bisa terus bersaing dalam menyajikan informasi dengan media online Harian Topskor punya strategi yaitu, tulisan berita indepth atau analisis yang disisipi data dan infografis.

Hal senada pun disampaikan oleh Redaktur Pelaksana Harian Topskor, Tri Cahyo Nugroho. Menurut Tri, Harian Topskor mencoba berita berbeda dari media lain. Strategi ini sudah dipraktikan sejak Harian Topskor pertama terbit. Tulisan tidak hanya sekedar laporan pertandingan, tapi menggali sisi lain.

Agar praktik tersebut berjalan lancar, tentu dibutuhkan sebuah manajemen redaksi agar strategi yang dijalankan Topskor dapat berjalan dengan lancar. Dalam media massa, dikenal juga sebuah konsep bernama manajemen redaksi. Manajemen redaksi memiliki penerapan fungsi-fungsi manajemen yaitu perencanaan, pengorganisasian, penggerakan, dan pengawasan di dalam kerja redaksi. Menurut Conrad C. Fink, keempat fungsi itu harus ada dalam kerja redaksi agar bisa memproduksi konten berita yang berkualitas.

\section{Perencanaan}

Sebelum membuat perencanaan, tim redaksi Topskor melakukan evaluasi konten dan kinerja wartawan. Evaluasi jadi agenda prioritas Topskor demi kelancaran dan ketahanan kualitas redaksi Topskor. Evaluasi biasanya membahas konten dari edisi sebelumnya, misal pada 19 Agustus 2018, Irfan Sudrajat sebagai Wakil Pemimpin Redaksi Topskor menyampaikan evaluasi konten tentang ASIAN Games. Hasilnya semua konten bagus dan semuanya harus bisa dipertahankan.

Perencanaan dibutuhkan oleh redaksi untuk menyusun konten berita. Perencanaan dalam redaksi Topskor sifatnya penting. Penentuan konten, pembagian kerja, dan evaluasi dilakukan dalam tahap perencanaan. 
Sebagai media olahraga, Harian Topskor harus memiliki rencana untuk menentukan berita olahraga apa yang akan ditulis dan dimuat. Apalagi berita olahraga setiap harinya selalu berubah dengan cepat, terlebih memasuki akhir pekan.

Di Harian Topskor, perencanaan termasuk dalam rapat redaksi. Setiap hari harus dibahas dan dikoordinasikan kepada staf redaksi yang lain. Rapat redaksi dilaksanakan setiap hari pukul 17.00 WIB yang dihadiri oleh pemimpin pedaksi (tentatif), wakil pemimpin redaksi, redaktur pelaksana, redaktur, dan wartawan. Hal yang dibahas adalah evaluasi dan penentuan konten. Menurut Wakil Pemimpin Redaksi Topskor, Irfan Sudrajat, seminggu sebelum pertandingan berlangsung, konten sudah harus dirancang. Hal ini dikarenakan pertandingan olahraga yang sudah memiliki jadwal yang jelas. Jadi, semua redaksi Topskor punya persiapan dan isu masingmasing ketika rapat dimulai.

"Sehari sebelumnya sudah harus mulai. Karena enggak mungkin jam 4 baru mulai, bahkan sebelum seminggu sebelumnya sudah fokus akan yang akan kita bikin. Dalam rapat redaksi semua disiapkan, harus rancang," kata Irfan Sudrajat.

Rapat dipimpin oleh wakil pemimpin redaksi. Diawali dengan pembahasan berita untuk edisi selanjutnya. Tak lupa juga membahas dan membandingkan headline di koran atau media online lainnya. Prinsip yang digunakan oleh Harian Topskor adalah jangan sampai ada berita yang asal-asalan. Konten dan isi berita harus selalu diperhatikan karena bisa berdampak bagi orang banyak atau Harian Topskor sendiri. Berita harus seimbang dan sesuai fakta serta data. Analisis pertandingan juga harus mengacu pada kompetisi atau pertandingan selanjutnya. Penulis harus mampu berimprovisasi dengan apa yang akan dia tulis.

Setelah perencanaan edisi selanjutnya selesai, semua jajaran redaksi membuat proyeksi liputan yang kemudian akan ditugaskan kepada wartawan. Proyeksi liputan dilakukan untuk melihat pertandingan atau kegiatan olahraga apa yang bisa dimuat dan dijadikan laporan utama. Namun, bila ada laporan pertandingan besar atau isu dari luar negeri (seperti big match atau derby), tulisan dari wartawan La Gazetta Dello Sport dan Marca bisa ditempatkan di halaman pertama. Misalnya berita laporan transfer Cristiano Ronaldo dari Real Madrid ke Juventus ditulis oleh wartawan La Gazetta Dello Sport. Bukan hanya itu, penulisnya juga memberikan analisis pemain dari klub apa saja yang bisa menjadi pesaing Ronaldo selama bermain di Juventus.

Setelah adanya proyeksi liputan, dibuatlah budgeting berita. Budgeting merupakan istilah ketika redaksi akan memilah dan menentukan berita apa yang layak dimuat di halaman pertama. Berita yang layak muat akan ditulis supaya semuanya tahu dengan apa yang akan diliput esok hari. Laporan rapat ini nantinya akan ditulis oleh sekretaris redaksi.

\section{Pengorganisasian}

Setelah tahap perencanaan, tahap berikutnya adalah pengorganisasian. Di dalam tahap ini, masing-masing jajaran redaksi mulai melaksanakan tugasnya setelah membuat perencanaan. Untuk pembagian penulisan berita dibahas dalam tahap pengorganisasian.

Setelah budgeting, ada yang disebut plotting atau penempatan wilayah liputan atau tanggung jawab rubrik. Dalam plotting ini juga, semua tulisan dan konten akan dipetakan sesuai tugas masing-masing. Dalam plotting wapemred dan redaktur bisa memiliki jabatan ganda atau 
Kajian Jurnalisme

ISSN 2549-0559 (cetak) ISSN 2549-1946 (online)

Volume 01 Nomor 02 Tahun 2018

double job karena adanya kompetisi atau ada agenda olahraga tertentu yang punya nilai pasar atau jual yang tinggi. Misalnya ASIAN Games atau Piala Dunia. Jadi dibutuhkan seseorang yang bisa mengurusi rubrik tambahan tersebut. "Ketika ada Asian games, berita bisa ada di halaman dua sampai empat,. Artinya apa yang masyarakat lagi ramai dibahas, itulah yang akan ditulis," kata Irfan Sudrajat.

Xaveria Yunita, salah satu wartawan Harian Topskor juga pernah mengemban bertanggung jawab tambahan di rubrik Piala Dunia 2018 lalu. Sejatinya, dia menulis berita dan analisis khusus rubrik Liga Italia. Meskipun begitu, Xave harus menulis berita di rubrik Liga Italia dan Piala Dunia selama dan pasca piala dunia.

\section{Penggerakan}

Penggerakan berarti saatnya pemimpin redaksi atau wakil pemimpin redaksi untuk mengarahkan staf redaksi bekerja sesuai dengan tugas dan tanggung jawab yang sudah dibahas dalam perencanaan dan pengorganisasian. Kegiatan yang dilakukan dalam tahap penggerakan ini adalah memproduksi berita dari peliputan hingga siap terbit.

Kegiatan produksi naskah berita dilakukan oleh semua redaksi Harian Topskor, termasuk wakil pemimpin redaksi. Wartawan tetap menulis berita. Tulisan dihasilkan dari liputan ke lapangan dan analisis data serta statistik permainan. Naskah yang sudah selesai kemudian diperiksa oleh redaktur atau editor masing-masing rubrik. Hasil akhir nanti akan diberi ke wakil pemimpin redaksi. Setelah selesai, tulisan kemudian dikirim ke tim desain untuk dimasukan ke dalam layout. Siklus ini menunjukan semua anggota redaksi, termasuk tim desain punya tanggung jawab untuk membuat konten.

Pada tahap ini, peneliti juga mengikuti salah satu kegiatan wartawan Harian Topskor yaitu Xaveria Yunita Melinda. Peneliti mengikuti Xave karena ingin melihat sudut pandang wartawan Topskor ketika menunaikan tugasnya. Dia adalah wartawan yang sudah bekerja di Topskor dari tahun 2011. Dia menulis di rubrik Liga Italia, tapi bisa bertambah bila ada kompetisi bergengsi seperti Piala Dunia.

Dia mulai datang ke kantor pukul 14.00 WIB dikarenakan dia tidak ke lapangan dan harus menulis berita dan analisis pertandingan. Wartawan lain biasanya datang pukul 15.00 atau 16.00. Xaveria menyusun sekitar dua sampai tiga tulisan yang akan dimuat esok hari. Selama menulis mata Xaveria fokus tertuju pada layar laptop dengan earphone di telinganya untuk mendengar penyataan atau komentar pelatih atau pemain usai pertandingan. Cara itu membuat Xave lebih leluasa membuat tulisan karena deadline cepat dan menerjemah tulisan. Kadang Xave menulis di online (Topskor.id) juga, tapi porsinya tidak banyak hanya dua sampai tiga tulisan. Biasanya tulisan Xave di Topskor.id lebih singkat. Semua tulisan ini sudah harus kelar dan selesai pukul 21.00 WIB agar tulisan bisa masuk dalam proses editing dan layout.

Ada pula wartawan yang bekerja di lapangan beritanya ditulis di laptop atau handphone. Kemudian dikirim via surat elektronik pukul 15.00 WIB. Tulisan ini akan diperiksa setelah rapat redaksi.

\section{Pengawasan}

Pengawasan adalah suatu usaha guna mengetahui kondisi dari kegiatan yang sedang dilaksanakan. Pengawasan bertujuan untuk menjelaskan sepanjang atau sejauh apa tingkat 
137 | Kajian Jurnalisme

ISSN 2549-0559 (cetak) ISSN 2549-1946 (online)

Volume 01 Nomor 02 Tahun 2018

capaian yang sudah atau dapat diraih dari kegiatan itu. Pengawasan dijalankan agar target yang diharapkan bisa berjalan dengan lancar.

Wakil pemimpin redaksi dan redaktur mengawasi wartawan ketika liputan dalam bentuk laporan kejadian di lapangan. Selain dalam bentuk laporan kejadian, ada pula pengawasan dalam bentuk konten. Menurut Irfan jangan sampai ada berita yang berat sebelah karena berpotensi merugikan Harian Topskor sendiri. Selain itu, integritas mereka ikut tercoreng.

Pengawasan dilakukan via grup Whatsapp agar memudahkan koordinasi antar anggota redaksi. Wapemred dan redaktur akan terus memantau kegiatan wartawan selama di lapangan. Ketika narasumber sulit dihubungi oleh wartawan, biasanya redaktur langsung menghubungi narasumber demi kemudahan penulisan berita.

Pengawasan dalam hal ini bukan hanya sekadar dalam dunia keredaksian. Secara alur kerja, redaksi Harian Topskor punya peraturan tertentu bagi seluruh awak redaksinya, yaitu wajib menulis berita, wajib datang ke kantor, berita harus berimbang, dan menjaga nama baik Harian Topskor. Sebagai media olahraga, Harian Topskor tidak punya ideologi media tertentu karena tujuan mereka melahirkan informasi olahraga yang mendalam, aktual dan eksklusif.

Pengawasan berlaku juga di media sosial. Bila ada anggota redaksi Harian Topskor yang berkilah dan mengunggah sesuatu yang membuat kegaduhan di media sosial, maka akan mendapat sanksi teguran bahkan pemecatan. Bukti tersebut benar adanya di mana wartawan Harian Topskor yang membuat kicauan di Twitter mengenai Ustad Abdul Somad. Wartawan tersebut bernama Zulfikar Akbar. Meskipun kasusnya berada di luar keredaksian, tapi apa yang diunggah oleh Fikar terlanjur viral. Setelah itu, warganet heboh dan ramai tagar \#boikottopskor. Redaksi kemudian mengambil keputusan tegas dengan menonaktifkan Fikar sehingga tidak bisa bekerja lagi di Harian Topskor.

Secara bisnis, Topskor juga empat pemasukan untuk perusahaan, yaitu penjualan koran, iklan, program rubrikasi, dan integrasi event. Meskipun punya tiga platform media (koran, website, dan e-paper), Harian Topskor punya fokus lini bisnis di koran, meskipun tidak mengesampingkan platform lainnya.

Elemen pertama adalah koran. Sulit dipungkiri bahwa salah satu pemasukan terbesarnya melalui koran. Pernyataan itu dibenarkan oleh Manajer Sirkulasi dan Distribusi Fardan Mustika dan Manajer Marketing Haderis Alkaf. Lewat penjualan koran, Harian Topskor dapat meraih pemasukan. Koran dijual seharga Rp 5.000 (Jabodetabek dan Bandung) dan Rp 5.500 (Luar Jabodetabek dan Bandung).

Elemen kedua adalah iklan. Iklan ada di media cetak dan online Topskor. Iklan berasal dari berbagai sponsor dan pengiklan yang sudah terikat kontrak kerja sama dengan Harian Tospkor. Ada beberapa pengiklan konsisten seperti Corsa, Hansaplas, obat kesehatan, dan lainnya. Iklan ini sifatnya ada yang konsisten dan periodik atau hanya mengikuti event Topskor, seperti ban mobil Corsa yang sudah cukup lama bekerja dengan Topskor dari tahun 2016 yang tergolong konsisten. Beberapa pengiklan cenderung tidak konsisten karena hanya mengikuti event atau kegiatan yang diselenggarakan Topskor contohnya Hansaplas.

Elemen ketiga adalah program rubrikasi. Rubrikasi adalah rubrik berisi kegiatan atau kompetisi besar berskala panjang. Program rubrikasi mengikuti permintaan sang klien. Klien 
jenis ini biasanya butuh media olahraga agar kegiatannya terus diberitakan selama kompetisi berlangsung, contoh kompetisi regular seperti Liga Indonesia (Liga 1).

Keempat adalah aktivasi atau event. Event adalah kerja sama antara pihak Topskor dan pihak klien atau pengiklan dalam bentuk kegiatan. Kegiatan yang biasa dilaksanakan adalah nonton bareng atau membuat kompetisi usia muda. Tidak seperti media pada umumnya, media olahraga punya acara nonton bareng atau kumpul komunitas tertentu. Nonton bareng biasanya juga bekerja sama tempat dengan cafe atau mal tertentu. Event atau kegiatan diharapkan bisa memberikan pemasukan bagi Topskor sebanyak-banyaknya. Event biasanya mengikuti lomba atau pertandingan dari kompetisi tertentu, misalnya kompetisi sepakbola besar seperti Liga Inggris, Liga Spanyol, Liga Italia, Liga Champions, atau MotoGP. Nonton bareng selanjutnya dikerucutkan lagi menjadi pertandingan besar (big match) agar meraih penonton yang besar, apalagi pertandingan tersebut melibatkan kedua pendudukung. Pendukung atau penonton banyak yang hadir di acara nonton bareng, tentu memberi pemasukan besar bagi Topskor.

Masuk pada bagian analisis, pada bagian ini peneliti akan menjabarkan terlebih dahulu perbandingan karakteristik cetak dan online. Menurut Elvinaro dkk, (2014:112), mengatakan bahwa media cetak bersifat periodesitas. Periodesitas menunjukan pada keteraturan terbitnya, bisa harian, mingguan, atau dwi mingguan. Peneliti melihat, karakteristik priodesitas menjadi kekurangan Harian Topskor dibanding media online. Mike Ward dalam bukunya berjudul Journalism Online (2002:19-26), menjelaskan bahwa kelebihan media online adalah (1) kemudahan akses, (2) jumlah berita yang diakses, (3) kecepatan akses, dan (4) mudah untuk disimpan atau sebarkan.

Kemudahan akses yang diberikan media online membuat penggunanya senang mencari berita di internet. Menurut Ward (2002), khalayak secara mudah dapat mengakses dokumen, berita, dari mana saja dan dari siapa saja dan kapan saja. Untuk mengakses media online, khalayak hanya butuh komputer, laptop, gawai atau smartphone yang terkoneksi internet agar dapat membaca berita secara digital. Berbeda dengan media cetak di mata pembacanya harus membeli korannya terlebih dahulu.

Media online punya kecepatan akses yang sulit disamakan oleh media cetak. Dalam Ward (2002), dijelaskan bahwa kecepatan yang dimaksud bukan hanya kecepatan internet saja, tapi juga dalam sekali waktu, khalayak bisa membaca berita dari berbagai sumber secara sekaligus, sehingga tidak butuh waktu lama. Menurut Ward (2002), media online punya karakteristik immediacy atau kesegeraan. Dengan kesegaran ini, maka kelebihan dari jurnalisme online adalah fleksibel dalam memuat berita. Namun, kesegaran kadang tidak diimbangi dengan verifikasi yang bagus. Media online sering mengabaikan kualitas isi berita dibandingkan kecepatan berita.

Media online punya karakteristik mudah untuk disimpan atau disebarkan. Menurut Ward (2002), berita yang didapat melalui media online akan dengan mudah disebarluaskan secara online, seperti e-mail, group discussion, sehingga khalayak saling berdiskusi bersama orang lain. Lebih lanjut James C. Froust (dalam Romli 2012:16) menjelaskan bahwa media online punya karakteristik storage an retrieval atau pengambilan penyimpanan berita tersimpan dan terarsipkan. Karakteristik tersebut sebenarnya bisa juga diterapkan dalam media cetak, tapi 
139 | Kajian Jurnalisme

ISSN 2549-0559 (cetak) ISSN 2549-1946 (online)

Volume 01 Nomor 02 Tahun 2018

butuh proses panjang dan butuh waktu yang lama agar koran bisa disimpan dan dilihat lagi dalam bentuk pertamanya. Sebab, kondisi kertas bisa berubah, entah karena sobek atau rusak.

Secara strategi redaksi Topskor dalam bersaing menyajikan konten, sebenarnya sudah banyak diterapkan juga oleh media online. Menurut Aun Rahman, strategi yang diterapkan oleh Topskor seperti tulisan atau berita panjang yang berisi data dan disertai gambar atau infografis sudah banyak ditulis oleh media online olahraga lain, seperti Panditfootball.com.

Secara manajemen redaksi, apa yang sudah diterapkan Harian Topskor sudah tepat sesuai dengan konsep manajemen redaksi Conrad C. Fink. Mereka membuat perencanaan sebelum konten dibuat jauh-jauh hari. Kemudian diorganisir agar setiap awak redaksi Topskor dapat bekerja sesuai dengan tugasnya membuat tulisan yang sudah disepakati dalam perencanaan.

Setelah ditentukan pembagian tugasnya, kemudian awak redaksi Topskor bekerja sesuai tugasnya. Mereka meliput, menulis, mengedit, dan menerbitkan berita. Dalam hal ini, seluruh divisi yang berkaitan dengan redaksi (seperti desain dan layout) ikut terlibat. Mereka membuat gambar yang berisi data dan fakta pertandingan atau profil pemain.

Kemudian, tiga hal tersebut dirangkum dalam bagian pengawasan, di mana seluruh anggota redaksi Topskor akan dievaluasi kinerjanya. Evaluasi ini dilakukan agar semua bagian redaksi Topskor dapat melaksanakan kewajibannya tanpa melanggar aturan yang ada.

Selanjutnya masuk dalam pembahasan sembilan elemen model kanvas. Pada analisis kali ini, peneliti akan menganalisis apakah Topskor.id bisa jadi salah satu lini bisnis lain perusahaan. Peneliti menggunakan model bisnis yang sama dengan analisis sebelumnya yaitu model bisnis kanvas Alexander Ostelwalder. Peneliti menggali bagaimana Topskor.id sebagai salah satu pemasukan Topskor di masa depan. Hal ini peneliti pilih karena melihat oplah koran Topskor yang semakin menurun, namun di sisi lain angka pengguna internet dan media online terus meningkat.

\section{Customer Segment (Segmentasi Konsumen)}

Harian Topskor mengincar generasi milenial dan kelas A-B. Menurut Haderis Alkaf, generasi milenial adalah generasi yang butuh informasi menarik. Harian Topskor sebagai media olahraga membikin diferensiasi dengan konten berita panjang dan ulasan pertandingan. Karena banyak media online hanya membuat berita singkat atau laporan saja.

Tetapi menurut Aun Rahman dan Ipe Islaminur, bisa jadi sebenarnya mengincar segmentasi yang berbeda. Aun berpendapat, dari konten, Harian Topskor hanya membuat konten yang selalu itu saja. Sedangkan Ipe beranggapan, segmentasi Topskor bisa dilihat dari iklan. Bila iklannya sedikit, berarti memang bukan kelas A-B. Bila kelasnya A dan B, iklannya harus premium (seperti iklan mobil, motor, atau barang mahal lainnya).

Dengan memanfaatkan kanal, Topskor.id, perusahaan punya target pembaca jelas. Menurut data APJII, penetrasi pengguna internet berdasarkan usia, dari umur 13-18 tahun berada di angka 75,50\% . Sedangkan umur 19-34 berada di angka 74,23\%. Angka ini cukup besar dan didominasi oleh generasi milenial yang terbiasa dengan internet.

Dari data tersebut, dapat dilihat ada korelasi antara temuan APJII dan target pembaca Topskor (15-29 tahun/46 persen total pembaca). Menurut company profile Topskor, berdasarkan demografi pembaca Topskor.id, usia 25-34 tahun atau 59,25 persen dominan 
mengakses dari total 3.292.576 pengakses. Bila digabungkan dari rentan usia 18-44 tahun, total pengakses mencapai 90,31 persen.

Data ini bisa menjadi rujukan Topskor guna memanfaatkan kanal Topskor.id. Dewasa ini, khalayak berbagai usia pandai memanfaatkan gawai, sehingga Topskor bisa menggaet khalayak lebih luas. Dengan berkonvergensi media pula, Topskor punya pesebaran wilayah lebih luas ke seluruh Indonesia, bahkan seluruh dunia.

\section{Value Proposition (Proposisi Nilai)}

Salah satu proposisi nilai yang dijual oleh Harian Topskor adalah berita yang eksklusif dan panjang. Sebagai media cetak olahraga, Harian Topskor menyajikan ulasan dan data sebagai penunjang informasi.

Menurut Aun Rahman, hal ini sebenarnya kurang efektif karena media online juga melakukan hal yang sama. Tapi Topskor sebagai media yang terkenal punya nilai lebih dan dikenal oleh masyarakat luas. Topskor memang dikenal selalu menyajikan konten yang penjang dan mendalam, sehingga dipercaya oleh masyarakat.

"Masalahnya media online melakukan hal yang sama. Dan lebih cepat. Masalahnya kan gini. Yang jadi masalah media cetak tuh, gimana caranya ngeluarin-nya lebih cepat dari media online. Beberapa jam setelah kejadian kemaren (suporter Persija yang tewas) Tirto dan beberapa media lain sudah bikin infografisnya. Sementara koran kayak PR, Tribun, Jawa Pos baru besoknya gitu," kata Aun Rahman.

Untuk selanjutnya, perusahaan harus memanfaatkan kanal Topskor.id sebagai saluran konten. Menjaga kualitasnya adalah salah satu cara terbaik. Topskor sudah dikenal masyarakat, hal itu dibuktikan dengan portofolio Topskor sebagai salah satu koran olahraga pertama di Indonesia.

\section{Channels (Saluran)}

Bila Harian Topskor punya saluran banyak seperti agen koran dan jasa cetak yang membutuhkan pengeluaran banyak, maka Topskor.id hanya butuh internet dan sosial media sebagai saluran. Semua konten dapat dimasukan ke dalam website.

Sama seperti Harian Topskor, Topskor.id menggunakan sosial media sebagai saluran penyebaran konten, di antaranya Facebook, Twitter, Youtube, dan Instagram. Untuk mengakses berita, khalayak tidak perlu membeli koran. Hanya dengan mengklik konten yang diinginkan, berita tersebut dapat dinikmati dalam gawai.

\section{Costumer Relationship (Hubungan Pelanggan)}

Di dalam situs Topskor.id, khalayak bisa memberikan tanggapan atau like di kolom komentar pada tiap berita atau ulasan yang ada. Berbeda dengan Harian Topskor di mana khalayak sulit berhubungan dengan Topskor karena tidak ada kolom opini pembaca.

Selain melalui situs, tentu saja interaksi dapat terjadi di media sosial. Pengguna Topskor.id dapat berinteraksi bersama pihak Topskor langsung melalui berbagai fitur yang disediakan media sosial. Fitur umum yang ada misalnya share (bagikan), berkomentar, dan menyukai posting-an dari Topskor. 
141 | Kajian Jurnalisme

ISSN 2549-0559 (cetak) ISSN 2549-1946 (online)

Volume 01 Nomor 02 Tahun 2018

Untuk menambah kepecerayaan pembaca, semua akun media sosial Topskor bisa terverifikasi atau diberi tanda centang. Tanda tersebut berguna agar pembaca mengetahui Topskor sebagai media yang sudah resmi dan terkenal.

\section{Revenue Stream (Arus Pendapatan)}

Dengan menjadikan Topskor.id sebagai salah satu pemasukan, maka perusahaan punya lima lini pemasukan, yaitu koran, iklan, aktivasi, rubrikasi, dan online. Bukan tidak mungkin ke depannya bila Harian Topskor tidak terbit, maka akan memangkas anggaran dan didistribusikan ke Topskor.id.

Topskor sebagai salah satu media olahraga terkenal bisa memanfaatkan website tersebut sebagai ladang bagi pengiklan. Terlebih iklan di Harian Topskor tidak banyak. Di masa depan, kemungkinan jumlah iklan terus bertambah dan lebih besar jumlah penawaran iklannya disebabkan segmentasi yang jelas.

\section{Key Resource (Sumber Daya Utama)}

Tidak banyak perubahan dalam sumber daya utama. Hanya peralihan secara digital dan membutuhkan internet agar bisa terus dikembangkan.

Topskor adalah media yang produknya informasi seputar olahraga. Maka sumber daya utamanya adalah sumber informasi itu sendiri. Konten yang biasanya fokus ke cetak, ke depannya dapat diutamakan di konten digital. Kerja sama dengan La Gazetta Dello Sport atau Marca pun harus dipertahankan guna informasi yang eksklusif.

Sumber daya manusia di dalam Topskor sekarang adalah pemimpin redaksi, redaktur pelaksana, redaktur, dan reporter. Dengan mengembangkan Topskor.id, awak redaksi turut fokus dan bertranformasi ke versi digital.

\section{Key Activities (Aktivitas Kunci)}

Aktivitas kunci adalah aktivitas yang harus diambil persusahaan agar beroperasi dengan sukses. Aktivitas kunci Topskor.id adalah membuat konten berita dan analisis. Salah satunya kelebihannya adalah eksklusifitas yang bekerja sama dengan media luar negeri.

Event yang diselenggarakan Topskor juga dapat dilaporkan lebih cepat lewat Topskor.id. Secara tidak langsung perubahan dari cetak menuju digital membuat pesebaran informasi juga lebih cepat dan pengeluaran yang sedikit.

\section{Key Partnership (Kemitraan Utama)}

Sejak pertama kali terbit, Topskor sudah memiliki relasi hubungan keredaksian dengan media asing, yaitu La Gazetta Dello Sport dan Marca. Khusus untuk kerja sama dengan media asing, Aun beranggapan belum tentu beritanya eksklusif karena banyak media nasional secara tidak langsung mengutip informasi yang sama. Sebuah berita dinilai eksklusifitas bila berita atau informasinya hanya diketahui oleh media tersebut.

"Sebenernya tidak signifikan. Kecuali ada berita yang bener-bener eksklusif dan Cuma Marca aja yang punya. Misalnya kayak, yang soal liga diberhentikan. Liga bener-bener diberhentikan bila bener-bener referendum Catalan. Tahun lalu. Itu yang dapet info awal-awal banget di Indonesia itu Topskor. Seinget saya. Masih fresh infonya. Salah satunya Topskor," kata Aun Rahman. 
Sedangkan pendistribusian, perusahaan berelasi dengan para agen atau loper koran. Untuk printing bermitra dengan Trio Wahana Green Printing. Konvergensi media yang dilakukan Topskor secara langsung menghapus dua kemitraan tersebut dan menghapus pengeluaran biaya kertas serta pengiriman barang.

\section{Cost Sturcture (Struktur Biaya)}

Struktur biaya adalah biaya yang harus dikeluarkan perusahaan untuk produksi yang meliputi kegiatan media massa. Dalam struktur biaya termasuk gaji wartawan, perawatan inventaris barang, relasi kerja sama La Gazetta dan Marca, serta pengeluaran lainnya.

Struktur biaya juga harus ditekan sebesar mungkin agar pendapat bisa lebih banyak dari pengeluaran. Hal tersebut sangat bisa dilakukan dengan memfokuskan Topskor.id sebagai pemasukan. Banyak pengeluaran dipotong dan dialokasikan ke dana lain seperti membayar programer atau ahli IT dan pemasangan internet.

Agar analisis bisnis ini semakin dalam, peneliti juga menggunakan konsep SWOT (strength, weakness, opportunity, threath). Peneliti telah memetakan Harian Topskor melalui konsep tersebut guna menganalisis apa saja yang bisa menjadi kekuatan, peluang, ancaman, dan kelemahan bagi Harian Topskor dalam bersaing dengan media online. Peneliti juga akan memilah analisis tersebut secara internal dan eksternal.

\section{Secara internal:}

\section{Strength}

Berdasarkan hasil penelitian dan pembahasan sebelumnya, peneliti melihat Topskor punya beberapa kekuatan dan dapat dipertahankan dalam persaingan dengan media online, di antaranya punya brand atau nama yang kuat, punya kekuatan tulisan mendalam atau indepth, dan event terkenal seperti nonton bareng dan Liga Topskor

Pertama, brand yang sudah terkenal. Harian Topskor sudah bertahan selama 14 tahun, itu bertanda bahwa Harian Topskor sudah punya brand yang dikenal oleh masyarakat luas.

Kedua, kekuatan tulisan. Hal tersebut dibuktikan lewat menjaga kualitas tulisan indepth disertai data dan infografis. Bukan itu saja, Topskor juga bekerja sama dengan La Gazetta Dello Sport dan Marca demi informasi yang lebih variatif dan beragam. Ketika Harian Topskor suatu saat berubah bentuk dalam versi digital, kekuatan ini senantiasa dipertahankan agar ciri khas tulisan indepth Topskor dapat terjaga.

Ketiga, kegiatan yang terkenal. Peneliti melihat kegiatan yang diselenggarakan Topskor dapat jadi peluang karena kegiatan tersebut sudah dikenal oleh khalayak luas. Apalagi kegiatan tersebut sudah memberikan efek, misalnya pemanggilan pemain Liga Topskor ke Timnas U16. Secara tidak langsung, hal tersebut juga menjadi daya jual Topskor kepada pengiklan.

\section{Weakness}

Peneliti melihat Harian Topskor punya kelemahan dari sisi konten dan bisnis. Secara konten, meskipun punya tulisan indepth dan data, Harian Topskor hanya menyajikan berita dan analisis pertandingan. Pasalnya, media online menerapkan cara serupa, bahkan lebih cepat dan jumlah berita lebih banyak. 
143 | Kajian Jurnalisme

ISSN 2549-0559 (cetak) ISSN 2549-1946 (online)

Volume 01 Nomor 02 Tahun 2018

Secara bisnis, Harian Topskor belum berani mencoba membuka lini usaha bisnis lain, misalnya aktif di sosial media dan membuat konten digital.

\section{Secara eksternal:}

\section{Opportunity}

Sebagai media cetak, Harian Topskor harus melihat peluang ke depan agar dapat terus bersaing dengan media online. Peneliti melihat ada beberapa peluang dapat diterapkan Topskor ke depannya, di antaranya kepercayaan pembaca, membuat konten baru, dan menjaga kegiatan yang ada.

Pertama, kepercayaan pembaca. Berdasarkan riset Nielsen Consumer \& Media View (CMV), pada kuartal III 2017 yang dilakukan di 11 kota dan mewawancara 17 ribu responden. Hasilnya adalah saat ini media cetak (termasuk koran, majalah dan jabloid) memiliki penetrasi sebesar 8 persen dan dibaca oleh 4,5 juta orang. Dari jumlah tersebut, 83 persen membaca koran. Alasan utama para pembaca masih memilih koran adalah karena nilai beritanya yang dapat dipercaya. Riset tersebut bisa diolah Harian Topskor agar kontennya terus dibaca oleh khalayak luas. Apalagi media online yang dikenal kurang verifikasi dan komprehensif dalam menyampaikan berita, membuat tingkat kepercayaannya masih diragukan.

Kedua, membuat konten baru. Peneliti melihat Harian Topskor dapat membuat kontenkonten (berita, analisis, atau infografis) baru. Konten tersebut bisa berupa analisis simulasi gim atau membuat konten digital. Pasalnya, banyak media online aktif menciptakan konten digital dan bekerja sama dengan pengiklan. Peneliti melihat Harian Topskor punya peluang tersebut, terlebih sudah bekerja sama dengan La Gazetta Dello Sport dan Marca, sehingga informasi yang didapat lebih banyak dan beragam.

Ketiga, mempertahankan kegiatan. Topskor punya kegiatan yang dikenal masyarakat luas, misal seperti Liga Topskor atau nonton bareng. Peneliti melihat kegiatan tersebut bisa jadi peluang mengenalkan Topskor kepada khalayak luas. Apalagi, Harian Topskor sudah mulai konvergensi dengan hadir dalam platform digital bernama topskor.id. Kegiatan tersebut bisa jadi peluang untuk mengenalkan Harian Topskor dan topskor.id kepada khalayak. Selain itu, prestasi dan kegiatan yang sudah terlaksana dapat ditingkatkan guna menggaet pengiklan lebih banyak lagi. Topskor juga dapat mengintegrasikan semua lini bisnis yang ada dalam bentuk konten digital sehingga pemasukan keuangan dapat ditingkatkan.

\section{Threath}

Peneliti melihat ancaman terbesar Harian Topskor, beberapa di antaranya adalah kecepatan media online dan kegiatan yang sama. sulit dipungkiri bahwa kecepatan media online adalah salah satu kekurangan juga untuk media cetak. Karena media online punya kemudahan memberikan informasi. Selain itu, internet dan media online juga sering diakses oleh milenial, di mana milenial termasuk target pembaca Harian Topskor.

Selain itu, kegiatan yang sudah dilaksanakan Topskor banyak dilakukan oleh media online. Dalam pembahasan sebelumnya, ada beberapa media online yang menyelenggarakan kegiatan seperti nonton bareng dan liga usia muda. Akan tetapi, Topskor sebenarnya punya konsistensi. 
Kajian Jurnalisme

ISSN 2549-0559 (cetak) ISSN 2549-1946 (online)

Volume 01 Nomor 02 Tahun 2018

Namun, banyaknya kegiatan yang sama, secara tidak langsung Topskor harus membuat diferensiasi. Dan, kegiatan yang sama itu jadi ancaman bagi Topskor.

\section{Simpulan}

Berdasarkan hasil penelitian, dapat disimpulkan manajemen strategi redaksi dan bisnis Topskor dalam menghadapi persaingan dengan media online di era konvergensi media, yaitu: (1) Harian Topskor mendefinisikan media online sebagai pesaing dari sisi informasi dan bisnis. Media online memiliki kecepatan yang sulit ditandingi Harian Topskor. Secara bisnis, media cetak dan online ada yang tergabung dalam grup perusahaan, sehingga dana media tersebut menjadi berlimpah. (2) Persaingan tersebut membuat Harian Topskor menyusun strategi, di antaranya tulisan indepth yang berisi berita dan analisis pertandingan dengan data dan infografis atau gambar. Strategi tersebut kemudian dipraktikan lewat manajemen redaksi. Manajemen strategi tersebut di antaranya adalah evaluasi dan perencanaan konten, pengorganisasian wilayah liputan dan pembagian jumlah tulisan, penggerakan meliput dan menulis berita, dan pengawasan kinerja atau sikap seluruh redaksi Harian Topskor. (3) Dalam menghadapi persaingan dengan media online dari sisi bisnis, Topskor menyusun strategi bisnis lewat beberapa cara, di antaranya iklan, rubrikasi, dan aktivasi. Iklan yang ada di Harian Topskor adalah hasil kerja sama dengan para klien. Iklan tersebut terintegrasi dengan program rubrikasi sehingga pengiklan bisa mendapatkan diskon ketika bekerja sama dengan Topskor. Hasilnya bisa berupa promo, teaser atau berita pesanan di halaman Harian Topskor. Aktivasi berupa kegiatan atau event yang diselenggarakan Topskor seperti liga usia muda dan nobar.

\section{Daftar Pustaka}

Ardianto, Elvinaro, Lukiati Komala \& Siti Karlina. (2014). Komunikasi Massa: Suatu Pengantar. Bandung: Simbiosa Rekatama Media.

Biagi, Shirley. (2013). Media/Impact An Introduction to Mas Media Tenth Edition. Boston: Wadsworth.

Diyah, Ramitasari. (2010). Potret Manajemen Media di Indonesia. Jakarta: Yayasan Pustaka Obor Indonesia.

Djuroto, Totok. (2004). Manajemen Penerbitan Pers. Bandung: Remaja Rosdakarya.

Fink, Conrad C. (1998). Strategic Newspaper Manajement. New York: Random

Hae, Nur Zaen, Rusdi Marpaung dan Hawe Setiawan. (2000). Konflik Multikultural Panduan Meliputi Bagi Jurnalis. Jakarta: Lembaga Studi Pers dan Pembangunan (LSPP) bekerjasama dengan The Asia Foundation dari USAID.

Hasibuan, Malayu S.P. (2008) Manajemen: Dasar, Pengertian, dan Masalah. Jakarta: Buki Aksara.

Hunger, David J. dan Thomas L. (1996). Wheelen. Manajemen Strategis. Yogyakarta: Penerbit Andi

Kartikawangi, Dorien. (2013). Strategi Komunikasi Bisnis Perusahaan Multinasional. Jakarta: PT Gramedia Pustaka Utama.

Kotler, Philip dan Kevin Lane Keller. (2009). Manajemen Pemasaran. Jakarta:Indeks

Kovach, B., \& Rosentiel. T. (2006). Sembilan Elemen Jurlatisme. Jakarta: Yayasan Pantau, ISAI, dan Kedutaan Besar Amerika Serikat di Jakarta.

Kusumaningrat, Hikmat, dan Purnama Kusumaningrat. (2005). Jurnalistik Teori dan Praktik. Bandung: Rosda 
145 | Kajian Jurnalisme

ISSN 2549-0559 (cetak) ISSN 2549-1946 (online)

Volume 01 Nomor 02 Tahun 2018

Leivrouw, Leah A. \& Sonia Livingstone. (2006). Handbook of New Media. Los Angeles, London, New

Delhi, Singapore, Washington DC: Sage Publication Ltd.

Liliweri, Alo. (1991). Memahami Peran Komunikasi Massa dalam Masyarakat. Bandung: Citra Aditya Bakti.

Littlejohn, S. W., \& Fross, K. A. (2009). Teori Komunikasi. Jakarta: Salemba Humanika.

McQuail, Dennis. (2011). Teori Komunikasi Massa. Jakarta: Salemba Humanika

Moleong, J Lexy, Prof. Dr. (2007). Metode Penelitian Kualitatif. Bandung: PT. Remaja Rosdakarya.

Mulyadi. (2001). Akuntansi Manajemen : Konsep, Manfaat dan Rekayasa, Edisi Ketiga. Jakarta:

Salemba Empat.

Mulyana, Deddy. (2005). Ilmu Komunikasi, Suatu Pengantar. Bandung: PT Remaja Rosdakarya.

Mulyana, Deddy. (2010). Metodologi Penelitian Kualitatif. Bandung : PT. Remaja

Osterwalder, A., and Pigneur, Y. (2010). Business Model Generation. New Jersey: Hoboken.

Pujileksono, Sugeng. (2015). Metode Penelitian Komunikasi. Malang: Intrans Publishing.

Purwanto, Iwan. (2012). Manajemen Strategi. Bandung: Yrama Widya

Rangkuti, Freddy. (2013). Analisis SWOT Teknik Membedah Kasus Bisnis. Jakarta: Gramedia Pustaka Utama

Romli, Asep Syamsul M. (2012). Jurnalistik Online. Bandung: Nuansa Cendikia Rosdakarya.

Santana, Septiawan K. (2005). Jurnalisme Kontemporer. Jakarta: Yayasan Pustaka Obor Indonesia.

Santana, Septiawan K. (2007). Menulis Ilmiah Metodologi Penelitian Kualitatif. Jakarta: Yayasan Pustaka Obor Indonesia.

Severin W. J., \& Tankard Jr., J. W. (2011). Teori Komunikasi: Sejarah, Metode, dan Terpaan di dalam Media Massa. Jakarta: Kencana. .

Siagian, Sondang P. (2000). Manajemen Strategik. Jakarta : PT Bumi Aksara.

Stoner, A.F. (1996). Manajemen: Edisi Bahasa Indonesia. New Jersey: Prentice-Hall Inc.

Sumandiria, AS Haris. (2005). Jurnalistik Indonesia, Menulis Berita dan Feature, Panduan Praktis Jurnalis Profesional. Bandung: PT Remaja Rosdakarya.

Ward, Mike. (2002). Journalism Online. Oxford: Focal Press.

Yin, Robert K. (2014). Studi Kasus Desain dan Metode. Jakarta: PT Raja Grafindo Persada.

Sumber jurnal:

Hasbi, Sirajjudin. (2014). "Jejak Sepakbola Dalam Media”. Pindai.org.

Prarstya, Nayarana Mahendra. (2014). "Geliat Surat Kabar Harian Olahraga di Indonesia”. Jurnal Komunikator, Vol 6, 45-58.

Irwansyah, Ahmad Prasetyadi. (2014). "Sejarah Konvergensi Media dalam Konteks Keindonesiaan". Jurnal Komunikasi Universitas Indonesia.

\section{Modul:}

Nugraha, Rahmadya Putra. (2012). "New Media and Society". Jakarta: Universitas Mercu Buana.

\section{Sumber website:}

http://fandom.id/feature/kultur/karena-sepak-bola-adalah-budaya-populer-yang-paling-populer/, diakses pada 30 Oktober 2018 pukul 14.20 WIB

http://wartakota.tribunnews.com/2017/12/27/wartawan-koran-olaharga-hina-ustaz-abdul-somaddipecat-setelah-itu-ini-yang-dia-tulis-lewat-twitter, diakses pada tanggal 2 November 2018 pukul 15.31 WIB

http://jurnal.unpad.ac.id/kajian-jurnalisme 
Kajian Jurnalisme

ISSN 2549-0559 (cetak) ISSN 2549-1946 (online)

Volume 01 Nomor 02 Tahun 2018

https://www.digitalnewsasia.com/tags/mobile-browser-satisfactory-index-survey, diakses pada 9 Agustus 2018 pukul $01.00 \mathrm{WIB}$

https://www.goal.com/id/berita/resmi-cristiano-ronaldo-hijrah-

kejuventus/1pwdlozqkboqs1xe39h2me6iyz diakses pada 26 Oktober 2018 pukul 10.31 WIB

https://www.indosport.com/sepakbola/20180527/keseruan-acara-nobar-final-liga-champions-barengindosport?image $=12$ diakses pada 2 November 2018 pukul 13.15 WIB

https://www.liputan6.com/bola/read/3586190/pemenang-dan-pecundang-terkait-kepindahan-cristianoronaldo-ke-juventus, diakses pada 26 Oktober 2018 pukul 13.14 WIB

https://www.merdeka.com/peristiwa/harian-bola-tutup-diganti-mingguan-bola-sabtu.html, diakses pada 23 Mei 2018 pukul 11:45

https://www.nielsen.com/id/en/press-room/2017/MEDIA-CETAK-MAMPU-MEMPERTAHANKANPOSISINYA.html, diakses pada 2 November 2018 pada pukul 11.12 WIB

https://www.panditfootball.com/analisa-pertandingan/211697/ANS/180711/menanti-kebangkitanserie-a-setelah-ronaldo-ke-juventus, diakses pada 2 November 2018 pada 19.10 WIB

https://www.topskor.id/detail/77753/Nobar-Final-Piala-Dunia-2018-di-Kemenpora-BerlangsungMeriah, diakses pada 2 November 2018 pukul 18.31 WIB

https://www.topskor.id/page/index/6/Tentang-Kami, diakses pada 28 Mei 2018 pukul 14.08 WIB

http://jurnal.unpad.ac.id/kajian-jurnalisme 